\title{
Effect of zinc deficiency on memory, oxidative stress and blood chemistry in rats
}

\author{
Osaretin A. T. EBUEHI * and Gabriel A. AKANDE \\ Department of Biochemistry, College of Medicine, University of Lagos, P. M. B. 12003, Lagos, Nigeria. \\ Corresponding author, E-mail: ebuehi@yahoo.com
}

\begin{abstract}
The effect of zinc deficiency on memory function, oxidative stress and blood chemistry in rats was investigated. Forty-two male $(65.0 \pm 2.78 \mathrm{~g})$ albino Sprague Dawley rats were equally divided into 3 groups, A, $\mathrm{B}$ and $\mathrm{C}$. The 3 groups of rats were fed zinc deficient diet, zinc adequate diet and reference diet, respectively, and water ad libitum daily for 30 days. Body weight, feed and water intake of the rats were computed every day. A shuttle box was used for the short-term and long-term memory tests of these rats fed the respective diets. Two criteria were considered as behavioural test; these include latency in entering dark chamber and time spent in the light chamber before entering the dark chamber at days 2, 9, 16 and 23 after the first day of training using the shuttle box. After the memory testing was conducted, rats were sacrificed by decapitation, blood was taken and brain excised. Total brain protein, plasma creatinine, reduced glutathione (GSH) levels, specific activities of acetylcholinesterase, superoxide dismutase (SOD), aspartate aminotransferase (AST), alanine aminotransferase (ALT) and alkaline phosphatase (ALP) were determined. The control diet supported significantly $(\mathrm{p}<0.01)$ higher body weight gain, feed intake and water intake than zinc adequate diet. The zinc adequate rat spent the longest time in the light compartment, followed by the control rat. The specific activity of AchE of zinc adequate rats was significantly higher than rats fed zinc deficient and control diet. Brain specific activity of SOD and reduced GSH of zinc adequate rats were significantly lower as compared with zinc deficient or control diet fed rats. There was no significant difference in the activities of plasma AST, ALT and ALP, creatinine level of rats fed zinc deficient, zinc adequate and control diets. Data of the present study indicate the effectiveness of the zinc adequate diet in memory retention and alleviation of oxidative stress in rats.
\end{abstract}

(C) 2009 International Formulae Group. All rights reserved.

Key words: Memory, oxidative stress, blood chemistry, zinc.

\section{INTRODUCTION}

Several articles on zinc deficiency and its effects on vital organs like brain, kidney and liver have been published (Hammond and Teary-Strancbury, 2002; Huckleberry and Robbins, 2002; Mocchegiani et al., 2006). However, there is very scanty report on the effects of zinc deficiency on memory files, learning tasks and cognitive behavior (Wallwork et al., 1984; Pollitt, 1993; Mocchegiani et al., 2006). The average adult requires approximately $0.2 \mathrm{mg} / \mathrm{kg}$ of zinc per day, however, this quantity cannot be used across the board (Hammond et al., 2002).

The risk of zinc deficiency (moderate or severe) is substantially increased by conditioning factors, such as, intestinal malabsorption, catabolic illness, alcoholism, cirrhosis, hemolytic anemia, renal failure, certain medications (diuretics, steroids and acetylcholinesterase inhibitors), blood loss by parasitic infestations, geophagia and an excessive loss of zinc due to sweating (Vallee and Auld, 1990; Mocchegiani et al., 2006 ). 
Numerous aspects of cellular metabolism are zinc-dependent (Cunningham et al., 1990; Noseworthy and Bray, 2005). Zinc plays important roles in growth and development, the immune response, neurological function and reproduction. On the cellular level, the biochemical roles of zinc can be divided into 3 categories, namely: catalytic, structural and regulatory (Murakami et al., 1987; Cunningham et al., 1990). Zinc plays an important role in the structure of proteins and cell membranes. Loss of zinc from biological membranes increases their susceptibility to oxidative damage and impairs their functions (Halsted et al., 1972).

Zinc is a necessary structural component of DNA-binding proteins that affects gene expression, and DNA is dependent on zinc for protection against damage (Cunningham et al., 1990). Zinc also plays a role in cell signalling and has been found to influence hormone release, nerve impulse transmission and in apoptosis. Zinc has been implicated to play a modulating role in synaptic transmission by interacting with specific sites on ionotropic neurotransmitter receptor proteins (Frederickson, 1989).

Oxidative stress is defined as the imbalance between biochemical processes leading to the production of reactive oxygen species (ROS) and those responsible for the removal of ROS, the so-called antioxidant cascade (Sayre et al., 2008). ROS are known to damage all cellular biomacromolecules and this damage can lead to secondary products that can be just as damaging as the initial ROS. The CNS is particularly vulnerable to oxidative stress on account of the high rate of $\mathrm{O}_{2}$ utilization, the relatively poor concentrations of classical antioxidants and related enzymes, and the high content of polyunsaturated lipids, the biomacromolecules must be susceptible to oxidation (Bray and Bettzer, 1990).

Zinc's function as an antioxidant was first proposed in 1990, based largely upon in vitro evidence that illuminated 2 distinct mechanisms. The first is the protection of proteins and enzymes against free radical attack or oxidation. The second mechanism by which zinc functions as an antioxidant is through the prevention of free radical formation by other metals, such as iron and copper (Staldman, 1986). One area of growing interest is the role of zinc as an antioxidant in the central nervous system (CNS) and maintains the integrity of the blood-brain barrier (BBB), thereby protects the brain from toxic agents (Halliwell and Gutteridge, 1999).

The zinc deficiency has been proposed to lead to nervous system disorders, including mental disturbances, loss of sensory acuity and impaired cognitive and psychological function (Halliwell and Gutteridge, 1999). Drugs that elevate, animic or inhibit the breakdown of Ach improve learning and memory performance (Lendahl et al., 1990). In the case of zinc deficiency, memory dysfunction occurs because the hippocampus has the ability to file memories, resulting in an ability to create new ones. Even if a memory is intact, without sufficient acetylcholine, one cannot connect one part of the memory with other (Jing et al., 1996).

Therefore, the present study was conducted to investigate the effect of zinc deficiency on memory, oxidative stress and blood chemistry in rats.

\section{MATERIALS AND METHODS \\ Formulation of zinc diets}

Two experimental diets (zinc adequate and zinc deficient) were formulated as presented in table 1. The ingredients used comprise of corn starch, egg white (powder), sucrose, vegetable oil, methionine, biotin, choline, vitamin mix and mineral mix. Egg white was supplemented with $30 \mathrm{mg} \mathrm{Zn/kg}$ of zinc adequate diet, while that of zinc deficient diet was supplemented with $4 \mathrm{mg} \mathrm{ZnSO}_{4} / \mathrm{kg}$. The vitamin mix $/ \mathrm{kg}$ diet consists of retinol (4.0 $\mathrm{mg})$, cholecalciferol (3.0 $\mathrm{mg})$, phylloquinone $(1.0 \mathrm{mg})$, tocopheryl acetate $(111.75 \mathrm{mg})$, thiamine hydrochloride $(10.0$ $\mathrm{mg}$ ), nicotinic acid (40 $\mathrm{mg}$ ), riboflavin (10 $\mathrm{mg})$, calcium pantothenate $(40 \mathrm{mg})$, folic acid $(1.8 \mathrm{mg})$, pyridoxine hydrochloride $(10 \mathrm{mg})$, vitamin $B_{5}(5.0 \mathrm{mg})$, ascorbic acid $(75 \mathrm{mg})$ and corn starch $(17623.2 \mathrm{mg})$. The mineral $\mathrm{mix} / \mathrm{kg}$ diet consists of $\mathrm{CaCO}_{3}(12.0 \mathrm{~g})$,

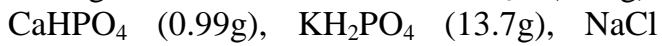
$(10.0 \mathrm{~g}), \quad \mathrm{MgSO}_{4} \quad(0.99 \mathrm{~g}), \mathrm{FeSO}_{4}(0.24 \mathrm{~g})$, $\mathrm{CuSO}_{4}(0.06 \mathrm{~g}), \mathrm{MnSO}_{4}(0.048 \mathrm{~g}), \mathrm{Co}(0.008 \mathrm{~g})$, $\mathrm{Kl}(0.0002 \mathrm{~g}), \mathrm{NH}_{4}\left(\mathrm{MO}_{7} \mathrm{O}_{37} .4 \mathrm{H}_{2} \mathrm{O}\right)(0.001 \mathrm{~g})$ (Wallwork et al., 1981).

The third diet which served as reference diet for the study, was a commercial feed manufactured by and purchased from 
Table 1: Composition of experimental Zinc diets.

\begin{tabular}{|c|c|c|}
\hline Ingredient & $\mathrm{Zn}$ adequate $\operatorname{diet}(\mathrm{g} / \mathrm{kg})$ & Zn deficient diet $(\mathrm{g} / \mathrm{kg})$ \\
\hline Corn starch & 566.5 & 566.5 \\
\hline Egg white (powder)* & 199.97 & 199.996 \\
\hline Sucrose & 100 & 100 \\
\hline Vegetable oil & 70 & 70 \\
\hline Vitamin mix & 20 & 20 \\
\hline Mineral mix & 40 & 40 \\
\hline Methionine & 1.5 & 1.5 \\
\hline Extra biotin & 0.004 & 0.004 \\
\hline Extra choline & 1.996 & 1.996 \\
\hline
\end{tabular}

Livestock Feeds Plc, Ikeja, Lagos State, Nigeria. The reference diet contained maize, sorghum, wheat meddlings, maize/sorghum offals, cotton seed cake and soya cake. The proximate compositions of these diets were assessed.

\section{Animal feeding}

Forty-two male $(65 \pm 2.78 \mathrm{~g})$ albino Sprague Dawley rats were collected from the Laboratory Animal Centre of the College of Medicine of the University of Lagos, Lagos. They were put in groups of three rats per cage and kept in a room with a temperature of $28 \pm 2$ ${ }^{\circ} \mathrm{C}$, and illuminated for $12 \mathrm{~h}$ per day $(0700$ $1900 \mathrm{~h}$ ). The rats were housed in metallic cages and fed commercial diet and water $a d$ libitum for 14 days of acclimatization. Care of all animals was as in accordance with the National Law on Animal Care and use (Zimmerman, 1983).

After acclimatization, the rats were equally divided into 3 groups and fed $\mathrm{Zn}$ deficient diet, $\mathrm{Zn}$ adequate diet and reference diet, respectively, for 30 days. Also, water was given ad libitum for 30 days. Body weights, feed and water intake of the rats were computed every other day. Feed efficiency was calculated by dividing body weight gained by feed intake.

\section{Training and learning procedure}

The apparatus used for training rats in order to assess their short-term and long-term memory was the shuttle box (Halas et al.,
1983). It consisted of two wooden compartments of identical dimensions ( 28 by $15 \mathrm{~cm}$ ). The two compartments were separated by a door in the middle part of this apparatus. Of the two compartments, one was illuminated and the other was dark. The door could be raised to permit entry of the rats into any of the two compartments. The floor consisted of $6 \mathrm{~mm}$ diameter wire rods spaced $1.7 \mathrm{~cm}$ between centres. The rods were connected to a set down transformer with a regular dimmer which could be switched on and off to deliver an instant scrambled foot shock to either compartment.

The training or learning task commenced after rats were acclimatized. At day $14\left(1^{\text {st }}\right.$ day of training), all rats were placed in the shuttle box and had access to the light or dark compartment for $1 \mathrm{~h}$. On day 2 of training, rats from each group were placed in the illuminated compartment and $30 \mathrm{sec}$ later the door was raised. Upon entering the dark compartment, the door was closed and a 1.5 $\mathrm{mA}$ constant current shock was applied for 2 $\mathrm{sec}$, after $20 \mathrm{sec}$, the rats were removed from the dark compartment and placed in their home cages.

For short-term testing, $24 \mathrm{~h}$ after training (day 2), each rat from the 3 groups was placed in illuminated chamber and $30 \mathrm{sec}$ later the door was raised, and the time spent in the light compartment before entering the dark compartment was recorded.

The learning procedure was repeated on days 9, 16 and 23. Learning skills acquired 
on days 16 and 23 depicted long-term memory.

\section{Plasma and brain analysis}

At the end of the learning procedure carried out on days 2, 9, 16 and 23 after the acclimatization of the rats, using the shuttle box, rats from each group were sacrificed by decapitation. Blood was taken into heparinized tubes and centrifuged at $2500 \mathrm{~g}$ for $10 \mathrm{~min}$. Plasma was carefully collected and used for further analysis. Brains were excised, wiped dry of blood, weighed and thoroughly perfused in ice-cold phosphate buffered saline, $\mathrm{pH}$ 7.4, until further analysis.

Brain tissues were homogenized with 5 volumes of ice-cold $50 \mathrm{mM}$ Tris $\mathrm{HCl}(\mathrm{pH} 7.4)$ containing $30 \mathrm{mM}$ sucrose. The homogenate was centrifuged at $1500 \mathrm{x} \mathrm{g}$ for $10 \mathrm{~min}$ to remove nuclei and cell debris. The resulting supernatant was then used for total protein determination, glutathione (reduced), superoxide dismutase and acetylcholinesterase activities.

Total brain protein levels were determined according to Lowry et al. (1951), using bovine serum albumin as standard. The concentration of reduced glutathione (GSH) was determined using the method of Ellman et al. (1961a). The GSH was expressed as $\mathrm{mMol} / \mathrm{mg}$ protein. Acetylcholineesterase activity in the brain homogenate was assayed as described by Ellman et al. (1961b) and its specific activity expressed as increase in absorbance per $\mathrm{min} / \mathrm{mg}$ protein.

The superoxide dismutase activity was assayed by its ability to inhibit the autooxidation of epinephrine, determined by the increase in absorbance at $480 \mathrm{~nm}$ (Sun and Zigman, 1978). The plasma creatinine was measured using a creatinine test kit (Sigma creatinine No 555 - A Kit). The concentration of creatinine in the control and tests were calculated and expressed as $\mathrm{mg} / \mathrm{dl}$.

The activities of plasma aspartate aminotransferase (AST, EC 2.6.1.1), alanine aminotransferase (ALT, EC 2.6.1.2), and alkaline phosphatase (EC, 3.1.3.1) were assayed at $37{ }^{\circ} \mathrm{C}$ according to the recommended principles (Steffensen et al., 1977) and using commercial kits manufactured by Baehringer, Mannheim, Germany and Roche, Switzerland.

\section{Statistical analysis}

Data were analyzed using Microsoft Excel Office 2003 and expressed as mean \pm S.D. The Student's t-test for independent samples was used to analyze the difference between the mean. Probability values less than $0.01 \quad(\mathrm{p}<0.01)$ were considered as highly significant.

\section{RESULTS}

Results of the changes in body weight, feed intake and water intake of rats fed $\mathrm{Zn}$ adequate diet, $\mathrm{Zn}$ deficient diet and reference diet for 30 days are presented in figures 1, 2 and 3. The reference diet supported significantly $(\mathrm{p}<0.01)$ higher body weight gain, feed intake and water intake than $\mathrm{Zn}$ adequate or $\mathrm{Zn}$ deficient diet. The $\mathrm{Zn}$ adequate diet had the highest feed efficiency, closely followed by the reference diet and lastly by the $\mathrm{Zn}$ deficient diet (Figure 4).

Table 1 shows the time spent by the rat in the light compartment before entering the dark compartment of the shuttle box. The $\mathrm{Zn}$ adequate rat spent the longest time in the light compartment, followed by the control rat and eventually the $\mathrm{Zn}$ deficient rat.

The specific activities of brain acetylcholinesterase (AchE), superoxide dismutase (SOD), the levels of reduced glutathione (GSH) and serum creatinine in brains of rats fed $\mathrm{Zn}$ adequate diet, $\mathrm{Zn}$ deficient diet and reference diet for 30 days are presented in table 2 . Brain specific activity of SOD and GSH level of $\mathrm{Zn}$ adequate rats were significantly $(p<0.01)$ lower as compared with $\mathrm{Zn}$ deficient or reference diet fed rats. The specific activity of AchE of $\mathrm{Zn}$ adequate rats was significantly $(\mathrm{p}<0.01)$ higher than in rats fed $\mathrm{Zn}$ deficient and reference diet. However, there was no significant $(\mathrm{p}<0.01)$ change in the serum creatinine level of $\mathrm{Zn}$ deficient, $\mathrm{Zn}$ adequate or reference diet.

Activities of aspartate aminotransferase (AST), alanine aminotransferase (ALT) and alkaline phosphatase (ALP) in plasma of rats fed $\mathrm{Zn}$ deficient diet, $\mathrm{Zn}$ adequate diet and reference diet for 30 days are shown in table 3 . There was no significant $(p<0.01)$ difference in the activities of plasma AST, ALT and ALP of rats fed Zn deficient, Zn adequate and reference diet. 


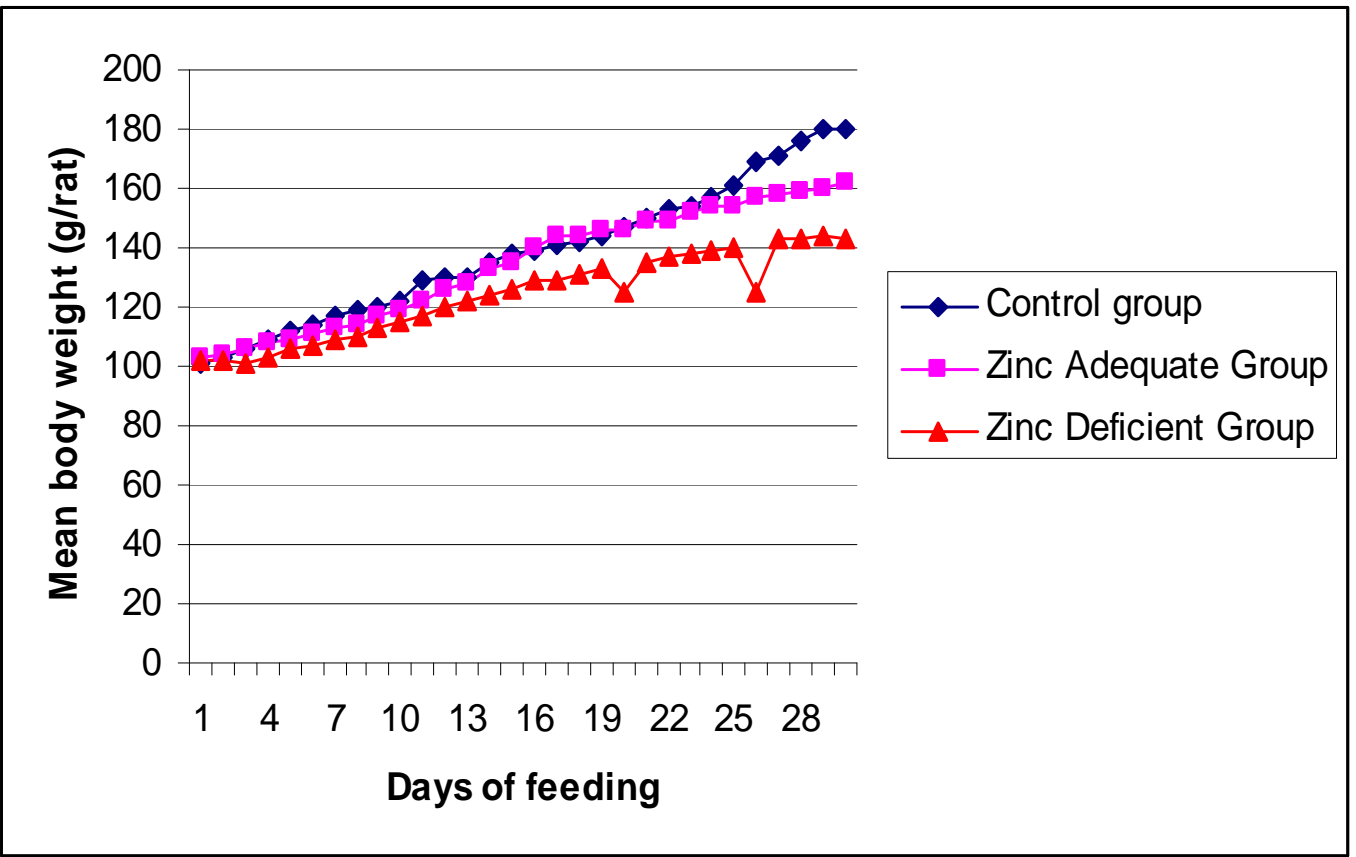

Figure 1: Changes in body weights of rats fed $\mathrm{Zn}$ adequate diet, $\mathrm{Zn}$ deficient diet and control diet for 30 days.

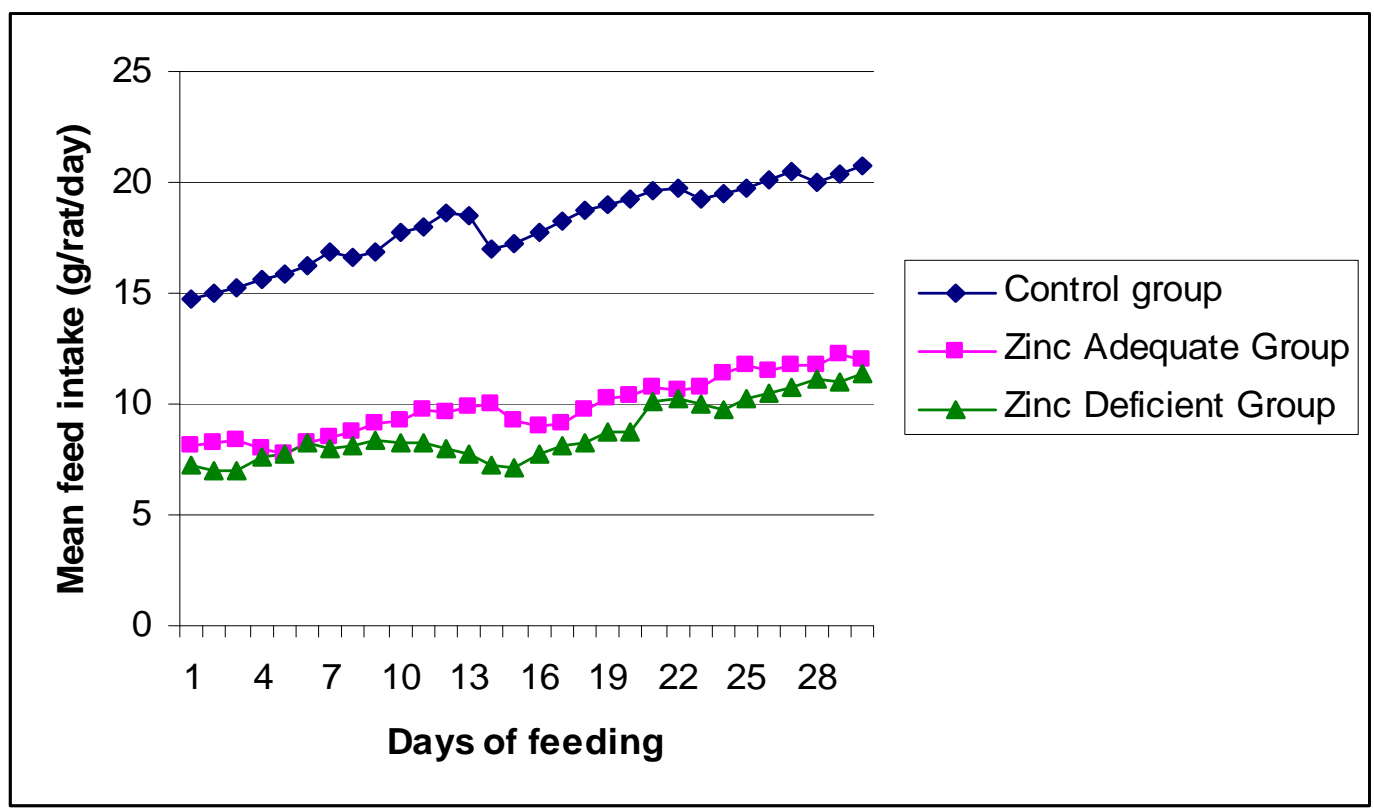

Figure 2: Changes in feed intake of rats fed on zinc adequate diet, zinc deficient diet and reference diet for 30 days. 


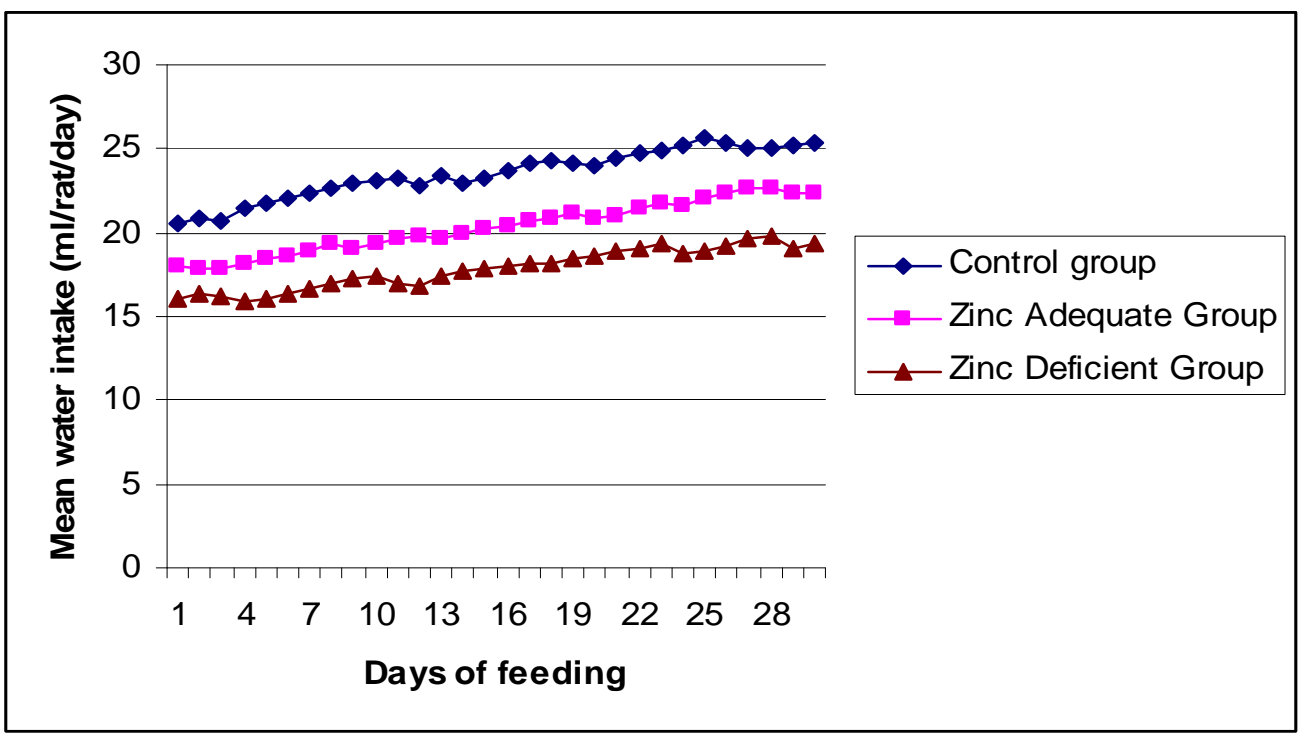

Figure 3: Changes in water intake of rats fed on zinc adequate diet, zinc deficient diet and reference diet for 30 days.

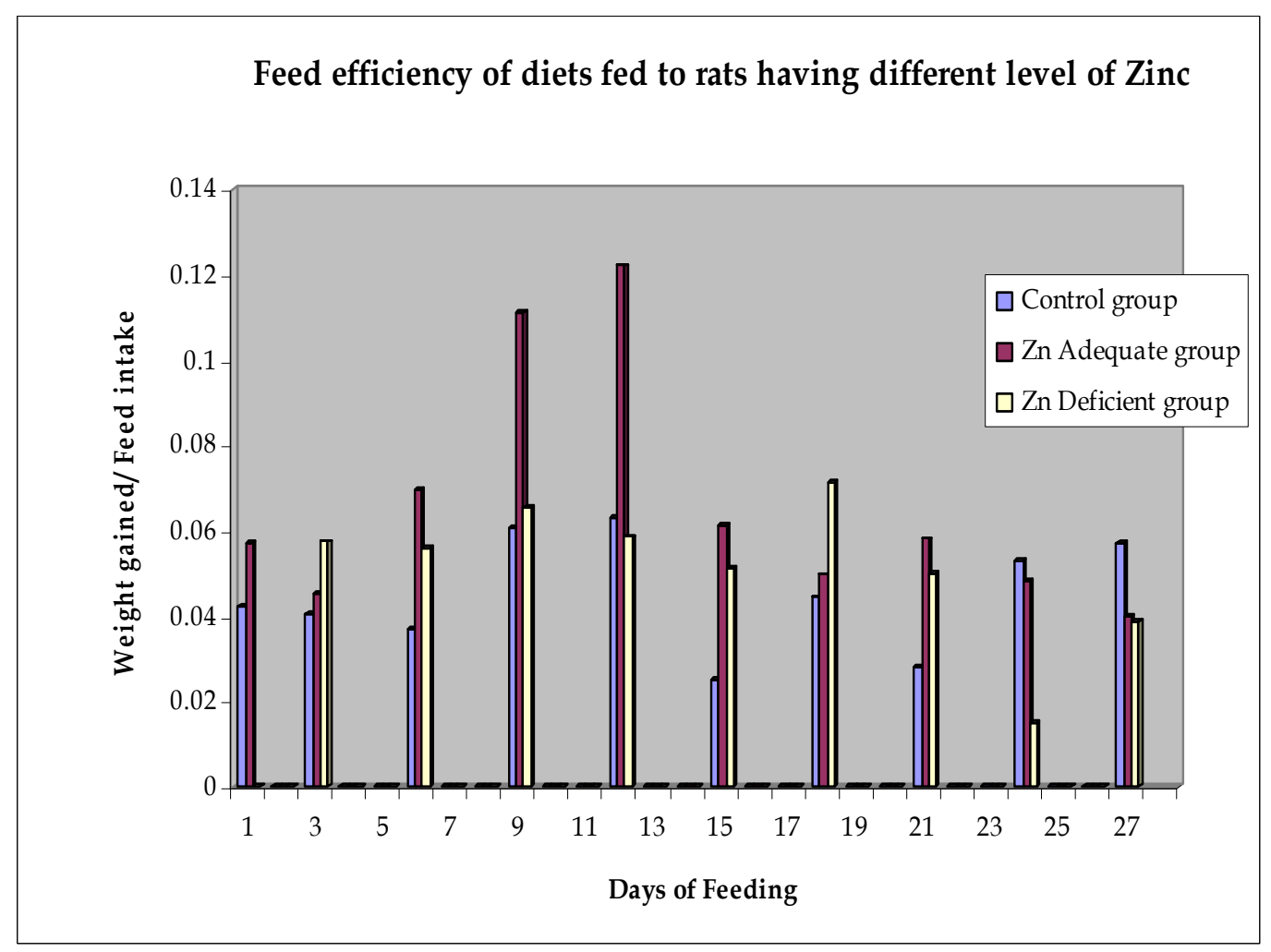

Figure 4: Feed efficiency of rats fed $\mathrm{Zn}$ adequate, $\mathrm{Zn}$ deficient and control diet for 30 days. 
Table 1: Time spent in the light compartment before entering the dark compartment by rats fed $\mathrm{Zn}$ adequate diet, $\mathrm{Zn}$ deficient diet and control diet during training using shuttle box ${ }^{1,2}$.

\begin{tabular}{lcccc}
\hline & \multicolumn{4}{c}{ Time (sec) spent on different training days } \\
\cline { 2 - 5 } Zinc diet & Day 2 & Day 9 & Day 16 & Day 23 \\
\hline Zn deficient & $17.28 \pm 3.93^{\mathrm{a}}$ & $7.02 \pm 2.41^{\mathrm{a}}$ & $4.10 \pm 1.58^{\mathrm{a}}$ & $4.20 \pm 1.83^{\mathrm{a}}$ \\
Zn adequate & $40.53 \pm 6.42^{\mathrm{b}}$ & $18.71 \pm 2.45^{\mathrm{b}}$ & $7.45 \pm 1.85^{\mathrm{b}}$ & $6.13 \pm 1.46^{\mathrm{b}}$ \\
Control & $22.64 \pm 5.13^{\mathrm{c}}$ & $10.76 \pm 3.08^{\mathrm{c}}$ & $5.22 \pm 1.34^{\mathrm{c}}$ & $5.10 \pm 1.39^{\mathrm{c}}$ \\
\hline
\end{tabular}

${ }^{\mathrm{T}}$ Values are expressed as Mean \pm S.D. $(\mathrm{n}=10)$ in triplicate determinations. ${ }^{2}$ Values carrying different superscripts vertically are significantly $(\mathrm{p}<0.01)$ different.

Table 2: Specific activities of brain acetylcholinesterase (AchE), superoxide dismutase (SOD), reduced glutathione (GSH) and plasma creatinine levels in brains of rats fed $\mathrm{Zn}$ adequate diet, Zn deficient diet and control diet for 30 days ${ }^{1,2}$.

\begin{tabular}{lcccc}
\hline Zinc Diet & $\begin{array}{c}\text { AchE } \\
(\mathbf{m o l} / \mathbf{m i n} / \mathbf{m g})\end{array}$ & $\begin{array}{c}\text { GSH } \\
(\mathbf{m o l} / \mathbf{m i n} / \mathbf{m g})\end{array}$ & $\begin{array}{c}\text { SOD } \\
(\mathbf{m o l} / \mathbf{m i n} / \mathbf{m g})\end{array}$ & $\begin{array}{c}\text { Plasma creatinine } \\
(\mathbf{m g} / \mathbf{d l})\end{array}$ \\
\hline Zn deficient & $0.002 \pm 0.004^{\mathrm{a}}$ & $0.188 \pm 0.015^{\mathrm{a}}$ & $5.062 \pm 0.84^{\mathrm{a}}$ & $0.643 \pm 0.021^{\mathrm{a}}$ \\
Zn adequate & $0.013 \pm 0.006^{\mathrm{b}}$ & $0.145 \pm 0.010^{\mathrm{b}}$ & $2.971 \pm 0.42^{\mathrm{b}}$ & $0.681 \pm 0.019^{\mathrm{a}}$ \\
Control & $0.008 \pm 0.002^{\mathrm{c}}$ & $1.506 \pm 0.014^{\mathrm{c}}$ & $4.863 \pm 0.39^{\mathrm{a}}$ & $0.690 \pm 0.019^{\mathrm{a}}$ \\
\hline
\end{tabular}

${ }^{1}$ Values are expressed as Mean \pm S.D. $(n=10)$ in triplicate determinations. ${ }^{2}$ Values carrying different superscripts vertically are significantly $(\mathrm{p}<0.01)$ different.

Table 3: Activities of aspartate aminotransferase (AST), alanine aminotransferase (ALT) and alkaline phosphatase (ALP) in plasma of rats fed $\mathrm{Zn}$ deficient diet $\mathrm{Zn}$ adequate diet and control diet for 30 days ${ }^{1,2}$.

\begin{tabular}{lccc}
\hline & \multicolumn{3}{c}{ Activity (U/I) } \\
\cline { 2 - 4 } Zinc Diet & AST & ALT & ALP \\
\hline Zn deficient & $148.25 \pm 3.15^{\mathrm{a}}$ & $51.62 \pm 2.74^{\mathrm{a}}$ & $86.37 \pm 2.54^{\mathrm{a}}$ \\
Zn adequate & $146.73 \pm 2.39^{\mathrm{a}}$ & $57.85 \pm 3.26^{\mathrm{a}}$ & $90.45 \pm 3.61^{\mathrm{a}}$ \\
Control & $141.30 \pm 6.52^{\mathrm{a}}$ & $52.17 \pm 1.63^{\mathrm{a}}$ & $85.72 \pm 3.49^{\mathrm{a}}$ \\
\hline${ }^{\mathrm{I}}$ Values are expressed as Mean \pm S.D. $(\mathrm{n}=10)$ in triplicate determinations. ${ }^{2}$ Values carrying different superscripts \\
vertically are significantly $(\mathrm{p}<0.01)$ different.
\end{tabular}

\section{DISCUSSION}

Results of the study showed that the control rats fed reference diet containing 15 $\mathrm{mg} \mathrm{ZnSO}_{4} / \mathrm{kg} /$ day ate more food, drank more water and gained more weight than the $\mathrm{Zn}$ adequate and $\mathrm{Zn}$ deficient groups. The reference diet was more acceptable to the rats. This may be due to better taste, flavour, odour, and other organoleptic attributes. In addition, the control diet contained fish meal, soya cake, oyster shell, bone meal, lysine and methionine, etc, which gave it a pleasant aroma, unlike the formulated diets which had raw vitamins and mineral salts. The sudden withdrawal from the experimental diets during the first few days of feeding could be responsible for the reduced body weight of rats; but as time went on the $\mathrm{Zn}$ adequate group responded rapidly to their diet while the response of $\mathrm{Zn}$ deficient rats was gradual.

The $\mathrm{Zn}$ adequate diet had the highest feed efficiency (weight gained/feed intake), 
this finding is an agreement with Moazedi et al. (2007). In addition, the International Zinc Nutrition Consultative Group (2004) also showed that children with acute diarrhoea when fed diets supplemented with zinc had a $15 \%$ lower probability of continuing their episode of diarrhoea as compared to the other test groups who had reduced body weights due to severe diarrhoea. Therefore, the $\mathrm{Zn}$ adequate diet had both therapeutic and nutritive effects.

There was significance in the time spent in the light compartment of the shuttle box by rats fed reference diet before entering the dark compartment as compared to the rats fed $\mathrm{Zn}$ adequate diet on days 2 and 9 . However, there was no significant $(p>0.05)$ difference on the days 16 and 23 of learning. This finding concurs with the results of Moazedi et al. (2007) who previously reported that there was a significant $(p>0.05)$ difference in the learning skills between rats whose mothers received $\mathrm{ZnCl}_{2} \quad$ (30 $\mathrm{mg} / \mathrm{kg} /$ day) or $\mathrm{Zn}$ supplemented diet at the stage of pregnancy and control group $(\mathrm{p}<0.01)$ 48 hours after training in the shuttle box, while 30 days after training, there was no significant $(\mathrm{p}>0.01)$ difference between $\mathrm{Zn}$ supplemented and control rats (Moazedi et al., 2007).

Working memory of days 2 and 9 can be regarded as the short-term memory while that of days 16 and 23 can be described as the long-term memory (Moazedi et al., 2007). As result of the training, the longer the time spent in the light compartment, the higher the learning skills. This was shown by the $\mathrm{Zn}$ adequate group which spent a longer time in the light compartment before entering the dark compartment, where they initially experienced a foot-scrambled shock, which made them to be reluctant to move quickly away from the light compartment unlike the $\mathrm{Zn}$ deficient and the control rats. This observation agrees with the findings that zinc deficiency in both humans and animals lead to impairment on passive avoidance learning (Takeda et al., 2005).

The reason for the high brain protein level in the $\mathrm{Zn}$ deficient group may be due to the high level of transferrin, albumin, and $\alpha-2$ macroglobulin in their unbound state. These transport proteins have been proposed as likely protein involved in the transport of zinc
(Prasad and Oberleas, 1970).The lower brain protein concentration in $\mathrm{Zn}$ adequate rat could relate to the involvement of transport proteins in the transport of zinc. Glutamatergic vesicles in the mossy fiber region contain ionic zinc, which is released with glutamate when the neurons are stimulated. In vitro studies indicate that oxidation of metallothionein by oxidized glutathione or analogous selenium compounds releases $\mathrm{Zn}$ to specific ligands like the GABA ( $\alpha$-amino butyric acid) and NMDA (N-methyl-D-aspartate) receptor, which participate in memory formation (Maret, 1995).

From the present study, the significant association between reduced brain glutathione level in the $\mathrm{Zn}$ deficient and control rat further confirms that zinc participates in neurotransmission. The reduced glutathione does not oxidize the metallothionein (Jing et al., 1998), but converted to the oxidized form (GSSG), when the glutamatergic neurons are stimulated by zinc. This explains why the reduced glutathione level was higher in the $\mathrm{Zn}$ deficient rat than in the control and $\mathrm{Zn}$ adequate rats.

The ALT and AST are enzymes involved in amino acid metabolism and used as a marker in liver diseases (Ebuehi and Asonye , 2007) since there was no significant $(\mathrm{p}<0.01)$ difference in the $\mathrm{Zn}$ adequate and $\mathrm{Zn}$ deficient or control rats, data suggest that liver damage was not detected. The quality and quantity of zinc consumed by rats in this study did not induce liver damage. This finding supports earlier studies conducted on mice and rats fed diets supplemented with 30,000 ppm zinc sulfate (more than a 1000fold in excess of the normal dietary intake) did not reveal changes in the histology of the liver or changes in the liver weight to body weight ratio after 13 weeks (Maita et al., 1981).

In a study with chicks fed zinc oxide (500 or $1000 \mathrm{mg} / \mathrm{kg}$ purified diet containing a basal zinc level of $70 \mathrm{mg} / \mathrm{kg}$,) no significant $(p<0.05)$ change in the activity of plasma ALT occurred after 14 days. The plasma AST activity was significantly elevated in a dosedependent manner with a $33.3 \%$ elevation at the highest dose, which the authors considered of doubtful physiological significance (Lu and Combs, 1988). 
The activity of Plasma Alkaline Phosphatase (ALP) of rats revealed that the $\mathrm{Zn}-$ fed adequate diet were significantly higher in activity than the control $(\mathrm{p}<0.05)$, while there was no significant difference between the control and the $\mathrm{Zn}$-deficient group. Some enzymes depend on zinc for their catalytic activity and are affected by the presence or absence of sufficient zinc (Vallee and Auld, 1990). These enzymes will not function properly with insufficient zinc. Alkaline phosphatase is a vital enzyme dependent on zinc. It releases or frees inorganic phosphates to be used in bone metabolism (Vallee and Auld, 1990). This explains the reason why rats fed $\mathrm{Zn}$ adequate diet had higher activity of ALP than in the $\mathrm{Zn}$ deficient or reference diet. Therefore, zinc deficiency culminates in impaired bone mineralization and may cause bone disease.

The specific activity of superoxide dismutase (SOD) in the brain homogenate of rats showed that the $\mathrm{Zn}$-fed adequate diet had lower specific activity than in the control, and $\mathrm{Zn}$-deficient fed rats. There was no significant $(\mathrm{p}<0.05)$ difference between the $\mathrm{Zn}$-deficient and the control. SOD is a marker for oxidative stress, because it prevents the cells from free radicals which can cause an imbalance in the antioxidant defense system, leading to oxidative stress (Farombi et al., 2004). It also revealed that loss of zinc from biological membranes increases their susceptibility to oxidative damage and impairs their functions (Halsted et al., 1972).

$\mathrm{Zn}$ acts as an antioxidant in two ways; first is the protection of proteins and enzymes against free radical attack, or oxidation (Canada and Calabrese, 1989). The second mechanism by which zinc functions as an antioxidant is through the prevention of free radical formation by other metals, such as iron and copper. Unlike highly reactive iron and copper, zinc does not readily undergo oxidation and reduction, or redox, reactions. When zinc, instead of iron or copper, is incorporated into proteins, free radical generation reactions that may otherwise occur are inhibited (Canada and Calabrese, 1989).

Previous works have also shown the consequences of the loss of BBB integrity due to oxidative stress during zinc deficiency (Bray and Bettzer, 1990). Ebuehi et al. (2003) previously reported oxidative stress during various trimesters of pregnancy in humans. They reported that increased levels of plasma lipid peroxidation and catalase activity during $2^{\text {nd }}$ and $3^{\text {rd }}$ trimesters of pregnancy were due to oxidative damage of maternal lipids, carbohydrates and proteins.

Creatinine is a nitrogenous waste product formed from the metabolism of creatine in skeletal muscle. The level of creatinine which is proportional to the muscle mass of an individual, is used as a test of renal function (Champe and Harvey, 1994). The present data suggest that kidney disease or muscle wasting in the rats did not occurred, since there was no significant difference in the plasma creatinine level of $\mathrm{Zn}$ adequate or $\mathrm{Zn}$ deficient or control rats.

The zinc adequate rat diet had the highest specific activity of brain acetylcholinesterase due to the rapid filing of memories by acetylcholine. Jing et al. (1996) previously reported that acetylcholinesterase serves as a biochemical marker for learning and memory. This observation indicates that the zinc adequate rat diet exhibited highest cognitive behaviour during learning and memory test using the shuttle box. The memory itself is thought to be put into storage by the neurotransmitter acetylcholine. Even if a memory is intact, without sufficient acetylcholine, one cannot connect one part of the memory with others. For example, you know the face, but cannot remember the name (Jing et al., 1996). Acetylcholinesterase hydrolyses acetylcholine and is used as a marker for cholinergic neural function. In addition, it is also regarded as a marker for developing rat brain and in neurodegenerative diseases (Mckay, 1997).

In conclusion, the data of the present study indicate that the effectiveness of the zinc adequate diet ( $30 \mathrm{mg} \mathrm{Zn} / \mathrm{kg} / \mathrm{day})$ in memory function, cognitive behaviour and alleviation of oxidative stress. In addition, the applicability of this level of zinc in diet is reliable and recommendable without any deleterious consequences in the kidney and liver.

\section{ACKNOWLEGDEMENTS}

The authors are grateful for the technical assistance received from $\mathrm{Mr}$ O. Ojo during the animal experiments and to $\mathrm{Mr}$ Samuel Akindele of the National Institute for 
Medical Research, Yaba, Lagos, Nigeria, for his assistance in the biochemical analysis.

\section{REFERENCES}

Bray TM, Bettzer WJ. 1990. The physiological role of zinc as an antioxidant. Free Radical Biol. Med., 8: 281-291.

Canada AT, Calabrese EJ. 1989. Superoxide dismutase: Its role in xenobiotic detoxification. Pharmacol. Ther., 44: 285-295.

Champe PC, Harvey RA. 1994. Lippincott's Illustrated Reviews; Biochemistry $\left(2^{\text {nd }}\right.$ edn). Lippincott Raven Publishers: New Jersey, USA; 303-340.

Cunningham BC, Bass S, Fub G, Wells JA. 1990. Zinc mediation of the binding of human growth hormone to the human prolactin receptor. Science, 250: 17091712.

Ebuehi OAT, Giwa-Osagie OI, Ebuehi OM, Giwa-Osagie OF. 2003. Oxidative stress during the various trimesters of pregnancy in humans. Nigerian Journal of Health and Biomedical Sciences, 2: 6164.

Ebuehi OAT, Asonye CL. 2007. Gender and alcohol consumption affect human serum enzymes, protein and bilirubin. Asian Journal of Biochemistry, 2(5): 330-336.

Ellman GL, Courtney KD, Andres KD, Featherstone RM. 1961a. A new and rapid colorimetric determination of reduced glutathione activity. Biochem. Pharmac., 7: 175-182.

Ellman GL, Courtney KD, Andres KD, Featherstone RM. 1961b. A new and rapid colorimetric determination of acetylcholinesterase activity. Biochem. Pharmac., 7: 88-95.

Farombi EO, Hansen M, Raven-Haren G, Moller P, Dragsted LO. 2004. Commonly consumed and naturally occurring dieting substances affect biomarkers of oxidative stress and DNA damage in the healthy rats. Food Chem. Toxicol., 42: 15-22.

Frederickson C. 1989. Neurobiology of zinc and zinc containing neurons. In International Review of Neurobiology (Vol 31), Smythies J, Bradley R (eds). Academic Press: New York; 145-238.

Halas ES, Eberhardt MJ, Diers MA, Sandstead HH. 1983. Learning and memory impairment in adult rats due to severe zinc deficiency during lactation. Physiol. Behav., 30: 371-381.

Halliwell B, Gutteridge M. 1999. Reproduction and Oxidative Stress. Free Radicals in Biology and Medicine $\left(2^{\text {nd }}\right.$ edn). Oxford Univ. Press: New York; 522-529.

Halsted JA, Ronaghy HA, Abadi P, Haghshenas M, Amerhakemi GH. 1972. Zinc deficiency in man. The Shiraz experiment. Am. J. Med., 53: 277-284.

Hammond CK, Tearley-Stransburg KM. 2002. Assessment of nutritional status and nutrition requirements. In Pharmacotherapy: A Pathophysiologic Approach $\left(5^{\text {th }}\right.$ edn), Dipiro JT, Talbert RC (eds). McGraw-Hill: New York; 2451-2452.

Huckleberry Y, Rollins CJ. 2002. Prevention of nutritional deficiencies. In Handbook of Nonprescription Drugs $\left(13^{\text {th }}\right.$ edn), Berardi RR, De Simone EM, Newton GD (eds). American Pharmaceutical Assoc.: Washington D. C.; 483-484.

International Zinc Nutrition Consultative Group (IZiNCG, 2004). Assessment of the risk of zinc deficiency in populations and options for its control. Food Nutr. Bull., 25(12): 191-202.

Jing NH, Kitani H, Morio I, Sakakura T, Tomcoka Y, Shiurba R. 1996. Expression of intermediate filament nestin during mouse brain development. Chinese J. Physiol. Sci., 12: 1-9.

Lendahl U, Zimmerman LB, Mckay RDG. 1990. CNS stem cells express a new class of intermediate filament protein. Cell, $\mathbf{6 0}$ : 585-595.

Lowry OH, Rosenbrough NJ, Farr AL, Randall RL. 1951. Protein measurement with Folin Phenol reagent. J. Biol. Chem., 193: 265-275.

Lu J, Combs GFJr. 1988. Effect of excess dietary zinc on pancreatic exocrine function in the chick. J. Nutr., 118: 681689.

Maita K, Hirand M, Mitsumori K, Takahashi K, Shirasu Y. 1981. Sub-acute toxicity studies with zinc sulphate in mice and rats. J. Pestic. Sci., 6: 327-336.

Maret W. 1995. Oxidative metal release from metallothionein via zinc-thiol/disulfide interchange. Proc. Natl. Acad. Sci. (USA), 91: 237-241. 
McKay RDG. 1997. Stem cells in the central nervous system. Science, 276: 66-71.

Moazedi AA, Ghotbeddin Z, Parham GH. 2007. Effects of zinc supplementation of pregnant rats on memory of their offsprings. Pak. J. Med. Sci., 23: 405409.

Mocchegiani E, Malavolta M, Marcellini F, Pawelec G. 2006. Zinc, oxidative stress, genetic background and immunosenescence; implications for heathy ageing. Immunity and Ageing., 3(6): 1742-1745.

Noseworthy MD, Bray TM. 2005. Zinc deficiency exacerbates loss in brain-brain barrier integrity induced by hyperoxia. Proc. Soc. Experimental Biol. and Medicine, 225: 175-182.

Murakami K, Whiteley MK, Routtenberg A. 1987. Regulation of Protein Kinase C activity by cooperative interaction of $\mathrm{Zn}^{2+}$ and $\mathrm{Ca}^{2+}$. J. Biol. Chem., 262: 1390213906.

Pollitt E. 1993. Iron deficiency and cognitive function. Ann. Rev. Nutr., 13: 521-537.

Prasad AS, Oberleas D, Wolf P, Horwitz JP, Miller ER, Luecke RW. 1969. Changes in trace elements and enzymes activities in tissues of zinc deficient pigs. Am. J. Clin. Nutr., 22: 628-637.

Sayre LM, Perry G, Smith MA. 2008. Oxidative stress and neurotoxicity. Chem. Res. Toxicol., 21: 172-188.

Staldtman ER. 1986. Oxidation of protein mixed function oxidation systems:
Implication protein turnover, ageing and neutrophil function. Trends Biochem. Sci., 11: 11-12.

Steffenson FM, Sorensen HT, Brock A, Vilstrup H, Lauriteen T. 1997. Alcohol consumption and serum liver derived enzymes in a Danish population aged 3050 years. Int. J. Epidemiol., 26: 92-99.

Sun M, Zigman S. 1978. An improved spectrophotometric assay for superoxide dismutase based on epinerphrine autooxidation. Analyt. Biochem., 90: 81-89.

Takeda A, Tamano H, Tochigi M. 2005. Zinc homeostasis in the hypocampus of zinc deficient young adult rats. J. Neurochem. Int., 46: 221-225.

Vallec BL, Auld DS. 1990. Zinc coordination, function and structure of zinc enzymes and other proteins. Biochemistry, 29: 5647-5659.

Wallwork JC, Fosmire GJ, Sandstead HH. 1981. Effects of zinc deficiency on appetite and plasma amino acid concentration in the rats. Br. J. Nutr., 45: 127-136.

Wallwork JC, Milne DB, Sandstead HH. 1984. Distribution of minerals and catecholamines in rat brain. Effects of zinc deficiency. In The Neurobiology of Zinc. Part B. Deficiency, Toxicity and Pathology, Frederickson CL, Howell GA, Kasarskis EJ (eds). New York; 49-64.

Zimmerman M. 1983. Ethical guidelines for investigation of experimental pain in conscious animal. Pain, 16(2): 109-110. 